\section{Bioaccumulation of trace}

\section{elements in lichens exposed \\ to geothermal and volcanic \\ activity from copahue-}

\section{caviahue volcanic complex, \\ patagonia, Argentina}

\section{Débora Fabiana Bubach ${ }^{1 *}$, Soledad Perez Catán', María Inés Messuti ${ }^{2}$, María Angélica Arribére ${ }^{1,3}$ and Sergio Ribeiro Guevara ${ }^{1}$}

'Laboratorio de Análisis por Activación Neutrónica, Centro Atómico Bariloche. CNEA. Av. Bustillo 9500, San Carlos de Bariloche, Argentina

${ }^{2} I N I B I O M A$, CONICET-UNComahue, Quintral 1250, San Carlos de Bariloche (8400), Argentina

${ }^{3}$ Instituto Balseiro (IB), Universidad Nacional de Cuyo (UNCuyo), Av. Bustillo 9500, San Carlos de Bariloche, Argentina
Received: 04 March, 2020

Accepted: 03 April, 2020

Published: 04 April, 2020

*Corresponding author: Débora Fabiana Bubach, Laboratorio de Análisis por Activación Neutrónica, Centro Atómico Bariloche. CNEA. Av. Bustillo 9500, San Carlos de Bariloche, Argentina, Tel: +54 2944 445240; Fax: +54 2944 445299; E-mail: bubachd@cab.cnea.gov.ar

Keywords: Air quality; Bioindicators; Sulfur; Natural emissions; South America; Volcanoes

https://www.peertechz.com

Check for updates

\begin{abstract}
The atmospheric pollution associated with the volcano Copahue activity was evaluated by analyzing the concentration of 33 elements including heavy metals in lichens. Fruticose thalli were collected between 7 and $18 \mathrm{~km}$ from the volcano crater, comprising a geothermal zone. Analytical data and geographic parameters were evaluated by Principal Component Analysis. Enrichment Factors was also calculated from elemental concentrations in the lichens. The Principal Components Analysis grouped the observations corresponding to the lichen samples in relation to the volcano crater distance, the thermal areas and the direction of the prevailing winds. The less impacted area by volcanic products presented a lower concentration of toxic elements ( $\mathrm{S}$ and $\mathrm{Hg}$ ) and a higher concentration of biological elements (Ca, $\mathrm{K}$, Mg and $\mathrm{Mn}$ ) than the other areas. All studied sites showed S and Se enrichments, even in the most distant areas from the volcano crater. The S concentrations in lichen recorded in areas of volcanic activity were higher for the volcanic complexes: Copahue-Caviahue and Puyehue-Cordón-Caulle (2800-12000 $\mu \mathrm{g} / \mathrm{g})$ than those reported for the rest of the world $(600-2800 \mu \mathrm{g} / \mathrm{g})$.
\end{abstract}

\section{Abreviations}

ASTM: American Society of Testing Materials; BCRU: Regional Center Bariloche Herbarium from the National University of Comahue; Río Negro; Argentina; CVCC: CopahueCaviahue Volcanic Complex; EF: Enrichment Factor; GT: Geological Tracer; IAEA: International Atomic Energy Agency; INAA: Instrumental Neutron Activation Analysis; $m$ a.s.l.: meters above sea level; P: Lichens of Protousnea Genus; PCA: Principal Component Analysis; PC1: Principal Component1; PC2: Principal Component2; PM: Particulate Material; QC:
Quality Control; REEs: Rare Earth Elements; U: Lichens of Usnea Genus; Sampling Sites; A: Achacosa pond; AR: Las Lecheras Stream; CA: Caviahue Village; CC: Caviahue Camping; CO: Copahue Village; E: Escondida Waterfall; H: Huelcupén Lake; M: Las Mellizas Pond; R26: Site Near to the Airfield; T: Trolope Pond

\section{Introduction}

The volcanic activity provides one of the major natural sources of contaminants at global and local scales $[1,2]$. In the last century, around 380 volcanoes were active in the world 
and about 80 are active today [3]. The aerosols emitted by volcanoes are considerably enriched in toxic components such as sulphur dioxide $\left(\mathrm{SO}_{2}\right)$, hydrogen sulphide $\left(\mathrm{H}_{2} \mathrm{~S}\right)$, hydrochloric acid ( $\mathrm{HCl})$, hydrofluoric acid ( $\mathrm{HF}$ ) and other minor components including trace elements as alkali metals, alkali earths, and transition metals [4]. It has been shown that amounts of Cd, $\mathrm{Hg}$, Se, $\mathrm{Cu}$ and $\mathrm{Zn}$ are comparable to anthropogenic sources in the Mediterranean area [5]. Environmental effects on local, regional and global scales can be significant depending on volcano characteristics and the processes that determine the magnitude of volcanic eruptions. The overall impact is a consequence of chemical and physical factors [4].

Control and monitor of air quality it is very important, at regional and/or global scales for adopting actions to protect the ecosystem and the people. The environmental quality can be evaluated by means of bioindicators such as lichens $[6,7]$. Likewise, in several cases they are used as quantitative tool owing to their ability to accumulate elements, some of them in relation to the environmental levels $[8,9]$. Qualitative determinations can be employed to determine the degree of environmental alteration. Contaminants can cause a decrease in the diversity and abundance of the lichen species and, in extreme cases; they can disappear from the impacted areas. Although the time trend of contaminants can be faithfully recorded by the artificial samplers or one-line measurement equipment, the lichens indicate the bioavailable fraction of the contaminant. Active volcanoes emit $\mathrm{SO}_{2}$ in the order of tons and the $\mathrm{S}$ concentrations reported in lichen for those volcanic zones are usually $0.5-1.5 \mathrm{mg} / \mathrm{g}$ [10-12].

In the Southern Volcanic Zone (SVZ) in South America, the direct impact of Puyehue volcano eruption, in 2011 was studied using lichens by Bubach et al. $[4,13]$ and by Nelson and Wheeler [14] in areas up to $100 \mathrm{~km}$ from the crater. Also Conti et al. [15] evaluated the effects of the impact at $1600 \mathrm{~km}$ approximately from the volcano, in Tierra del Fuego, Argentina.

The volcanoes in the Andes Mountains play an important role in global climate change and the composition of the atmosphere in the Southern Hemisphere [3]. There are approximately more than 200 potentially active volcanoes along the Andes Mountains of South America [16]. Copahue is an active stratovolcano located in central Chile, in the Central part of the SVZ, at the Argentina borderline, integrating the Copahue-Caviahue Volcanic Complex (CVCC). It shows an extensive record of recurrent explosive eruptions since 1750 to the present [17], which affected the Copahue zone, a natural protected area with aboriginal settlements and tourist recreation.

Previous studies of the elemental composition in lichens after the Puyehue volcano eruption in 2011 showed some element concentrations were related to the volcano distance and the preponderant plumes [4]. In addition, the geothermal activity is another natural source of toxic compounds and elements as sulfhydryl acid $\left(\mathrm{H}_{2} \mathrm{~S}\right), \mathrm{As}, \mathrm{Br}$, and $\mathrm{Hg}$ for the environments $[12,18]$. Based on these results it is expected to find that the elemental compositions in lichens from CCVC will present differences in geothermal zones from distant areas in a gradient affected by predominant direction of the ash plumes.

The aim of this work is to check the influence of the distance to the volcano crater, preponderant plumes and thermal areas over the element concentrations accumulated in fruticose lichens in the surroundings to the CCVC.

\section{Materials and methods}

\section{Study area}

The CCVC rises in a sector of the Northern Patagonian Andes, in the Neuquén province, Argentina ( $37^{\circ} 47^{\prime}-37^{\circ} 55^{\text {' }} \mathrm{S}$ and $\left.70^{\circ} 55^{\prime}-71^{\circ} 10^{\prime} \mathrm{O}\right)$. This sector is a plateau with elevations exceeding $2000 \mathrm{~m}$ a.s.l. and characterized by glacifluvial valleys at the northeast sector (Puerta del Trolope) and a considerable amount of wetlands associated with water springs, pools of water and bubbling mud, and fumaroles [17]. The vegetation is dense in the adjacent area to the watershed, alternating with semi desert and steppe vegetation in the peripheral areas. The Araucaria araucana (araucaria or pehuén) forests on slopes and rocky outcrops below $1800 \mathrm{~m}$ a.s.l. are characteristics of this region [19].

The emissions of the recurrent explosive eruptions of Copahue volcano are swept eastbound by the dominant westerly winds, following the valley of Caviahue and Trolope.

\section{Sampling and sample preparation}

The sampling areas were chosen considering the plume directions of the most influential Copahue eruptions since 1992 until 2016 and also, the permanent gas emissions from the crater and hot springs (Figure 1). All the sampling sites in the areas are located towards the east of the volcano, which are listed and described on Table 1.

Specimens of Usnea and Protousnea species were collected according to their presence and availability (random walk) in March 2017 (Table 1). Thalli of Usnea sp. were collected from rocks, approximately $50 \mathrm{~cm}$ above the ground, and Protousnea sp. were taken from Araucaria araucana at least to one meter above the ground. A surface soil sample was taken in each area where the lichens were collected.

The samples were collected and processed using latex gloves and a titanium knife, and stored in sterile polyethylene bags. A fraction of lichen specimens were separated for later identification. The lichens for the elemental analysis were conditioned based on the IAEA biomonitoring of air pollution by Instrumental Neutron Activation Analysis (INAA) methodological recommendations $[20,21]$. The residues of substrates and other non-lichen materials were removed under dissecting stereo microscope at room temperature $\left(22^{\circ} \mathrm{C}\right)$. Afterwards, the lichens were submerged for two seconds in ASTM grade 1 water three times and dried in a laminar flow hood. Composite sample from each site was done with five to ten lichens thalli of similar size and characteristic. Afterwards, composite samples were thinly cut, homogenized to a fine powder, and aliquots (130 to $180 \mathrm{mg}$ ) were put in quartz ampoules for analysis. 


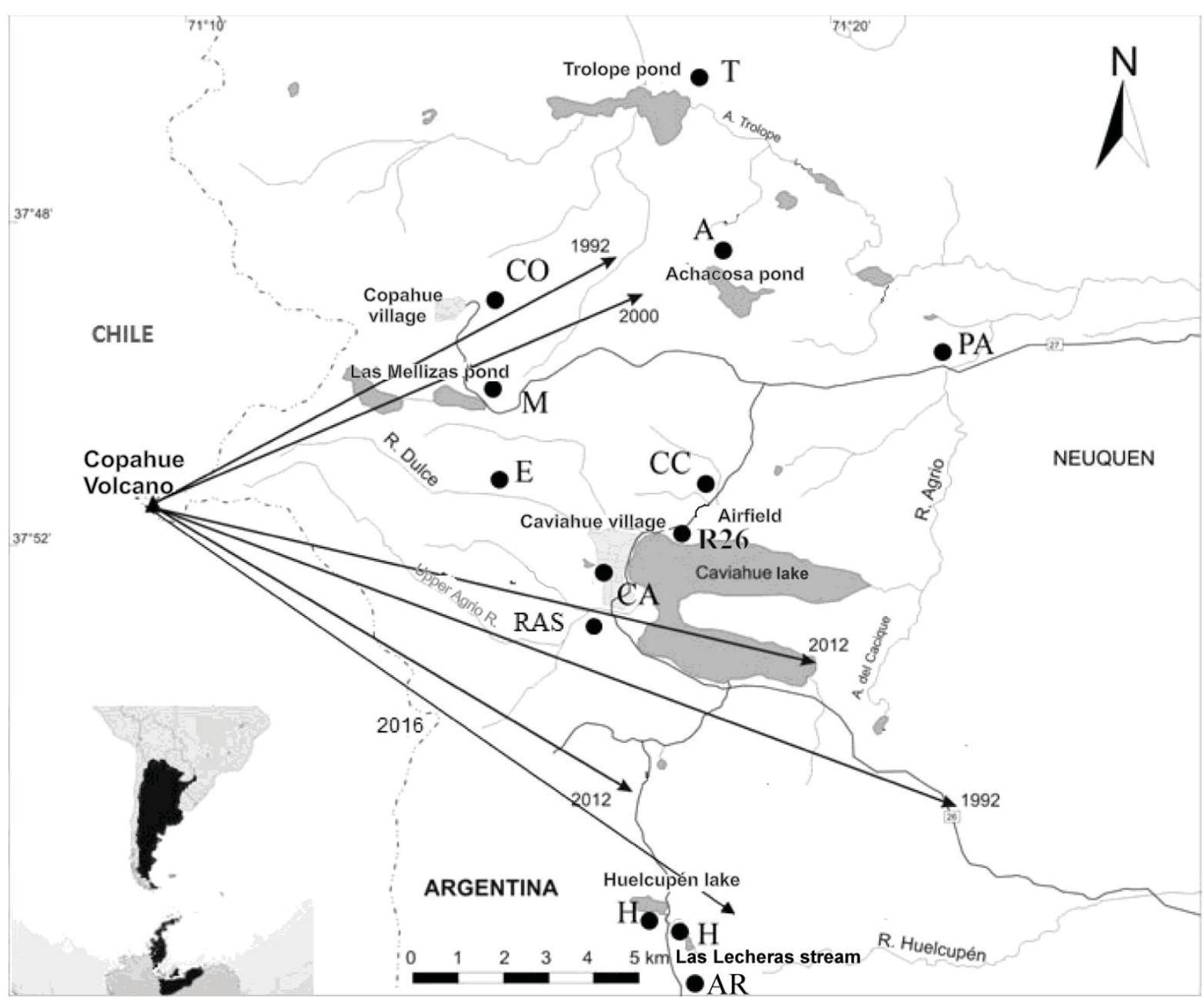

Figure 1: (A) Anterior segment mass (B) CT scan of orbit (C) Histological stain showing mixed spindle B and pigmented epithelioid cells (D) Appearance of eye after excision of anterior segment mass.

Table 1: Sampling areas description in the Copahue-Caviahue Volcanic Complex.

\begin{tabular}{|c|c|c|c|c|c|c|c|c|}
\hline Code & Areas & Area characteristics & $\begin{array}{l}\text { Numbers of } \\
\text { sampling } \\
\text { sites within }\end{array}$ & $\begin{array}{l}\text { Lichens } \\
\text { genus }\end{array}$ & Latitude & Longitude & $\begin{array}{c}\text { Altitude } \\
\text { (m) }\end{array}$ & $\begin{array}{l}\text { Distance to } \\
\text { the volcano } \\
\text { crater }(\mathrm{km})\end{array}$ \\
\hline $\mathbf{T}$ & Trolope pond & Steppe vegetation & 2 & Usnea & $37^{\circ} 46^{\prime} 31^{\prime \prime} \mathrm{S}$ & $71^{\circ} 02^{\prime} 12^{\prime \prime} \mathrm{W}$ & 1564 & 14 \\
\hline $\mathbf{A}$ & Achacosa pond & Steppe vegetation & 1 & Usnea & $37^{\circ} 48^{\prime} 26^{\prime \prime} \mathrm{S}$ & $71^{\circ} 01^{\prime} 43^{\prime \prime} \mathrm{W}$ & 1564 & 13 \\
\hline $\mathrm{CO}$ & Copahue village & Hot springs and semi desert & 2 & Usnea & $37^{\circ} 48^{\prime} 59^{\prime \prime} \mathrm{S}$ & $71^{\circ} 05^{\prime} 27^{\prime \prime} \mathrm{W}$ & 2030 & 8 \\
\hline M & Las Mellizas pond & Hot springs and semi desert & 2 & Usnea & $37^{\circ} 50^{\prime} 14^{\prime \prime} \mathrm{S}$ & $71^{\circ} 05^{\prime} 16^{\prime \prime} \mathrm{W}$ & 1996 & 7 \\
\hline PA & Puente del Agrio & Semi desert & 1 & Usnea & $37^{\circ} 49^{\prime} 43^{\prime \prime} \mathrm{S}$ & $70^{\circ} 58^{\prime} 53^{\prime \prime} \mathrm{W}$ & 1549 & 18 \\
\hline $\mathbf{E}$ & Escondida waterfall & Nothofagus pumulio forest & 3 & Protousnea & $37^{\circ} 51^{\prime} 23^{\prime \prime} \mathrm{S}$ & $71^{\circ} 05^{\prime} 13^{\prime \prime} \mathrm{W}$ & 1673 & 7 \\
\hline $\mathbf{C A}$ & Caviahue village & A. Araucana forest & 5 & Protousnea & $37^{\circ} 52^{\prime} 24^{\prime \prime} \mathrm{S}$ & $71^{\circ} 03^{\prime} 23^{\prime \prime} \mathrm{W}$ & 1643 & 10 \\
\hline $\mathbf{C C}$ & Caviahue Camping & $\begin{array}{l}\text { Steppe vegetation and } \\
\text { Austrocedrus chilensis trees }\end{array}$ & 3 & Protousnea & $37^{\circ} 51^{\prime} 2^{\prime \prime} \mathrm{S}$ & $71^{\circ} 01^{\prime} 49^{\prime \prime} \mathrm{W}$ & 1650 & 12 \\
\hline R26 & Near to the airfield & Steppe vegetation & 3 & Protousnea & $37^{\circ} 51^{\prime} 44^{\prime \prime} \mathrm{S}$ & $71^{\circ} 02^{\prime} 41^{\prime \prime} \mathrm{W}$ & 1650 & 11 \\
\hline RAS & Upper Agrio river & A. Araucana trees & 4 & - & $37^{\circ} 52^{\prime} 47^{\prime \prime}-53^{\prime} 24^{\prime \prime} \mathrm{S}$ & $71^{\circ} 3^{\prime} 43^{\prime \prime}-4^{\prime} 7^{\prime \prime} \mathrm{W}$ & $1622-1715$ & $9-10$ \\
\hline \multirow[t]{2}{*}{ H } & \multirow[t]{2}{*}{ Hualcupén lake } & \multirow{2}{*}{$\begin{array}{l}\text { Steppe vegetation and } A \text {. } \\
\text { araucaria trees }\end{array}$} & 6 & Protousnea & $37^{\circ} 56^{\prime} 36^{\prime \prime}-44^{\prime \prime} \mathrm{S}$ & $71^{\circ} 02^{\prime} 10^{\prime \prime}-19^{\prime \prime} \mathrm{W}$ & 1547 & 15 \\
\hline & & & 1 & Usnea & $37^{\circ} 56^{\prime} 36^{\prime \prime}-44^{\prime \prime} \mathrm{S}$ & $71^{\circ} 02^{\prime} 10^{\prime \prime}-19^{\prime \prime} \mathrm{W}$ & & \\
\hline AR & Las Lecheras stream & $\begin{array}{l}\text { Steppe vegetation and } A . \\
\text { araucaria trees }\end{array}$ & 2 & Protousnea & $37^{\circ} 58^{\prime} 21^{\prime \prime} \mathrm{S}$ & $71^{\circ} 01^{\prime} 37^{\prime \prime} \mathrm{W}$ & 1522 & 18 \\
\hline
\end{tabular}

Surface soil samples, taken at 2 to $3 \mathrm{~cm}$ deep with plastic spoons were placed in plastic jars with screw caps. All the samples were kept frozen at $-20^{\circ} \mathrm{C}$ until lyophilization. Dried soils were sieved with a $125 \mu \mathrm{m}$ mesh and aliquots of 50 to 100 $\mathrm{mg}$ were weighed in plastic containers for the analysis.

The geographical location data, such as latitude, longitude, 
altitude and distance from the volcano, were obtained by GPS (Garmin GPSMAP 76S).

\section{Lichen identification}

The lichen specimens were identified based on fresh selected material and on herborized specimens deposited in BCRU herbarium to compare. A standardized protocol for lichen studies was used to identify each specimen [22] and they were examined using dissecting stereo microscope (Olympus SZ30) and a light microscope (Leitz Laborlux 11). Anatomical features were studied on hand-cut sections mounted in water and in lactophenol cotton blue; $10 \% \mathrm{KOH}$ or $1 \%$ Lugol's Iodine solution and after a $10 \% \mathrm{KOH}$ pretreatment.

\section{Elemental analysis}

The elemental composition of samples was measured by Instrumental Neutron Activation Analysis (INAA). The samples were irradiated in the RA-6 research nuclear reactor, Centro Atómico Bariloche, Argentina (thermal and epithermal fluxes: $\phi_{\mathrm{th}}=1.5 \times 10^{13} \mathrm{n} \cdot \mathrm{cm}^{-2} \cdot \mathrm{s}^{-1}$ and $\phi_{\mathrm{epi}}=8 \times 10^{11} \mathrm{n} \cdot \mathrm{cm}^{-2} \cdot \mathrm{s}^{-1}$, respectively). Three gamma-ray spectra, with different decay times, were collected using an intrinsic HPGe detector 30\% relative efficiency, and 4096-channel analyzer. The spectra were analyzed by using the GAMANAL routine included in the GANAAS package distributed by International Atomic Energy Agency (IAEA), and the elemental concentrations were determined using the parametric method. The elements analyzed were antimonium (Sb), Arsenic (As), Barium (Ba), Bromine ( $\mathrm{Br}$ ), Cesium (Cs), Cobalt (Co), Lanthanum (La), mercury (Hg), Selenium (Se), Thorium (Th), Titanium (Ti), Vanadium (V) and Uranium (U); the essentials Calcium (Ca), iron (Fe), Magnesium $(\mathrm{Mg})$, Manganese $(\mathrm{Mn})$, potassium $(\mathrm{K})$, and sodium ( $\mathrm{Na})$; the Rare Earth Elements (REE) such as Cerium (Ce), Dysprosium (Dy), Europium (Eu), Lutetium (Lu), Samarium (Sm), Terbium $(\mathrm{Tb})$, and Ytterbium ( $\mathrm{Yb})$, and the Trace Elements Hafnium (Hf), Rubidium (Rb), Scandium (Sc), Strontium (Sr), Tantalum
(Ta) and Zinc (Zn). Analytical errors were computed as the propagation of the uncertainties associated with the nuclear parameters, the efficiency of the gamma-ray detection system, the neutron flux determinations, and the area of the specific emission considered.

The lichen samples were analyzed together with the IAEA 336 Lichen Reference Material for analytical Quality Control (QC), showing good agreement with the recommended values; these results are reported on Table 1 and Table 2, Supplementary Material.

Sulphur contents were measured by Combustion Infrared Detection Technique (LECO) method (HF-100 Induction Furnace model 777-400 SN 675, 0.5\% precision) [23].

\section{Data analysis}

The normality of the element concentrations in the lichens was tested applying the Kolmogorov-Smirnov Tests and it is shown on Table 3, Supplementary Material.

Principal Component Analysis (PCA) was performed on the element concentrations and geographical parameters (distance, altitude, longitude) as variables using the Spearman rank correlation. The significantly related variables are highlighted in bold.

The soil samples composition include lithophile elements, such as the REEs, which correlate linearly among them. For this reason, the elements from soil particulate entrapped in the lichen thalli were identified by linear regressions with a lanthanide element used as a Geological Tracer (GT) based on the Pearson Test. Samarium is usually proposed as GT because it normally presents the lowest analytical uncertainty respect to other REE when samples are analyzed by INAA [13].

The statistical analysis was performed with XLSTAT program (Copyright 1995-2009 Addinsoft). The statistical significance level was taken as $\mathrm{p} \leq 0.05$.

Table 2: Spearman correlation coefficients among elements and geographical variables.

\begin{tabular}{|c|c|c|c|c|c|c|c|c|c|c|c|c|c|c|c|c|c|c|c|}
\hline Variables & Altitude & Latitude & Longitude & Distance & $\mathrm{Sb}$ & As & $\mathrm{Ba}$ & $\mathrm{Br}$ & $\mathrm{Ca}$ & $\mathrm{Ce}$ & $\mathrm{Cs}$ & $\mathrm{Co}$ & $\mathrm{Cr}$ & Dy & $\mathrm{Eu}$ & Hf & $\mathrm{Fe}$ & $\mathrm{La}$ & $\mathrm{Lu}$ \\
\hline Altitude & 1 & -0.66 & 0.63 & -0.89 & 0.45 & -0.058 & 0.44 & 0.25 & -0.27 & 0.40 & 0.44 & -0.12 & 0.088 & 0.41 & 0.22 & 0.50 & 0.29 & 0.31 & 0.22 \\
\hline Latitude & & 1 & -0.31 & 0.46 & -0.22 & 0.29 & 0.0022 & -0.21 & 0.38 & -0.047 & -0.61 & 0.45 & 0.19 & -0.024 & 0.095 & -0.16 & -0.12 & -0.047 & 0.067 \\
\hline Longitude & & & 1 & -0.68 & 0.62 & 0.33 & 0.21 & 0.25 & -0.50 & 0.059 & 0.46 & -0.21 & 0.32 & 0.027 & -0.13 & 0.53 & 0.40 & -0.020 & -0.17 \\
\hline Distance & & & & 1 & -0.43 & -0.066 & -0.43 & -0.23 & 0.25 & -0.33 & -0.38 & 0.070 & -0.19 & -0.34 & -0.18 & -0.51 & -0.26 & -0.24 & -0.18 \\
\hline $\mathrm{Sb}$ & & & & & 1 & 0.54 & 0.44 & 0.58 & -0.30 & 0.31 & 0.48 & 0.13 & 0.50 & 0.054 & 0.11 & 0.67 & 0.65 & 0.27 & 0.082 \\
\hline As & & & & & & 1 & 0.11 & 0.52 & -0.23 & -0.011 & 0.16 & 0.34 & 0.66 & -0.22 & -0.12 & 0.50 & 0.54 & -0.02 & -0.15 \\
\hline $\mathrm{Ba}$ & & & & & & & 1 & 0.37 & 0.15 & 0.48 & 0.22 & 0.66 & 0.49 & 0.39 & 0.40 & 0.71 & 0.59 & 0.42 & 0.35 \\
\hline $\mathrm{Br}$ & & & & & & & & 1 & -0.29 & -0.04 & 0.34 & 0.28 & 0.41 & -0.059 & -0.18 & 0.47 & 0.55 & -0.03 & -0.20 \\
\hline $\mathrm{Ca}$ & & & & & & & & & 1 & 0.42 & -0.63 & 0.39 & -0.17 & 0.42 & 0.58 & -0.32 & -0.43 & 0.43 & 0.62 \\
\hline $\mathrm{Ce}$ & & & & & & & & & & 1 & \#\#\#\# & 0.33 & 0.014 & 0.77 & 0.96 & 0.36 & 0.14 & 0.97 & 0.94 \\
\hline $\mathrm{Cs}$ & & & & & & & & & & & 1 & -0.11 & 0.30 & -0.17 & -0.18 & 0.67 & 0.71 & -0.0034 & -0.20 \\
\hline $\mathrm{Co}$ & & & & & & & & & & & & 1 & 0.64 & 0.16 & 0.35 & 0.43 & 0.46 & 0.33 & 0.31 \\
\hline $\mathrm{Cr}$ & & & & & & & & & & & & & 1 & -0.25 & -0.10 & 0.69 & 0.77 & -0.015 & -0.13 \\
\hline Dy & & & & & & & & & & & & & & 1 & 0.79 & 0.14 & -0.11 & 0.73 & 0.79 \\
\hline $\mathrm{Eu}$ & & & & & & & & & & & & & & & 1 & 0.19 & -0.023 & 0.96 & 0.99 \\
\hline Hf & & & & & & & & & & & & & & & & 1 & 0.92 & 0.33 & 0.13 \\
\hline $\mathrm{Fe}$ & & & & & & & & & & & & & & & & & 1 & 0.14 & -0.083 \\
\hline $\mathrm{La}$ & & & & & & & & & & & & & & & & & & 1 & 0.93 \\
\hline $\mathrm{Lu}$ & & & & & & & & & & & & & & & & & & & 1 \\
\hline
\end{tabular}

In bold, significant values (except diagonal) at $\alpha=0.05$ 


\begin{tabular}{|c|c|c|c|c|c|c|c|c|c|c|c|c|c|c|c|c|c|c|c|}
\hline Variables & $\mathrm{Mg}$ & $\mathrm{Mn}$ & $\mathrm{Hg}$ & $\mathrm{K}$ & $\mathrm{Rb}$ & $\mathrm{Sm}$ & $\mathrm{Sc}$ & $\mathrm{Se}$ & $\mathrm{Na}$ & $\mathrm{Sr}$ & $\mathrm{S}$ & $\mathrm{Ta}$ & $\mathrm{Tb}$ & Th & $\mathrm{Ti}$ & $\mathrm{U}$ & $\mathrm{V}$ & $\mathrm{Yb}$ & $\mathrm{Zn}$ \\
\hline Altitude & -0.35 & -0.35 & 0.53 & -0.54 & 0.38 & 0.32 & 0.59 & -0.07 & 0.20 & -0.21 & 0.12 & 0.48 & 0.26 & 0.54 & 0.22 & 0.41 & 0.11 & 0.23 & 0.31 \\
\hline Latitude & 0.42 & 0.22 & -0.43 & 0.68 & -0.61 & 0.014 & -0.14 & 0.41 & 0.10 & 0.36 & -0.36 & -0.23 & 0.058 & -0.25 & 0.040 & -0.018 & -0.016 & 0.076 & -0.26 \\
\hline Longitude & -0.24 & -0.52 & 0.35 & -0.36 & 0.31 & -0.060 & 0.43 & 0.19 & 0.38 & -0.51 & 0.017 & 0.51 & -0.084 & 0.48 & 0.50 & 0.51 & 0.47 & -0.14 & 0.33 \\
\hline Distance & 0.30 & 0.42 & -0.42 & 0.56 & -0.23 & -0.24 & -0.57 & -0.11 & -0.27 & 0.19 & 0.010 & -0.48 & -0.20 & -0.52 & -0.30 & -0.44 & -0.18 & -0.19 & -0.11 \\
\hline $\mathrm{Sb}$ & 0.11 & -0.24 & 0.52 & -0.095 & 0.32 & 0.18 & 0.65 & 0.35 & 0.52 & -0.26 & 0.097 & 0.67 & 0.16 & 0.57 & 0.68 & 0.60 & 0.67 & 0.10 & 0.30 \\
\hline As & 0.40 & -0.15 & 0.14 & 0.28 & 0.06 & -0.09 & 0.28 & 0.67 & 0.65 & -0.22 & 0.030 & 0.48 & -0.094 & 0.40 & 0.62 & 0.56 & 0.61 & -0.15 & -0.031 \\
\hline $\mathrm{Ba}$ & 0.31 & 0.35 & 0.15 & -0.081 & 0.07 & 0.44 & 0.77 & 0.21 & 0.61 & 0.38 & -0.034 & 0.64 & 0.39 & 0.60 & 0.49 & 0.57 & 0.38 & 0.38 & 0.15 \\
\hline $\mathrm{Br}$ & 0.30 & -0.046 & 0.39 & -0.13 & 0.21 & -0.14 & 0.37 & 0.28 & 0.46 & -0.18 & 0.29 & 0.43 & -0.15 & 0.30 & 0.51 & 0.38 & 0.54 & -0.21 & -0.14 \\
\hline $\mathrm{Ca}$ & 0.26 & 0.45 & -0.50 & 0.31 & -0.60 & 0.50 & -0.048 & 0.18 & -0.28 & 0.89 & -0.37 & -0.39 & 0.54 & -0.27 & -0.38 & -0.36 & -0.40 & 0.61 & -0.26 \\
\hline $\mathrm{Cs}$ & -0.14 & -0.052 & 0.40 & -0.56 & 0.90 & -0.093 & 0.41 & -0.26 & 0.49 & -0.50 & 0.28 & 0.74 & -0.14 & 0.69 & 0.54 & 0.54 & 0.56 & -0.21 & 0.42 \\
\hline $\mathrm{Ce}$ & 0.066 & 0.17 & 0.16 & 0.057 & -0.036 & 0.98 & 0.71 & 0.27 & 0.12 & 0.45 & -0.031 & 0.29 & 0.97 & 0.44 & 0.11 & 0.34 & 0.00 & 0.95 & 0.28 \\
\hline Co & 0.70 & 0.61 & -0.27 & 0.36 & -0.17 & 0.32 & 0.41 & 0.44 & 0.64 & 0.59 & -0.11 & 0.37 & 0.32 & 0.33 & 0.39 & 0.38 & 0.35 & 0.32 & -0.10 \\
\hline $\mathrm{Cr}$ & 0.49 & 0.08 & -0.034 & 0.076 & 0.16 & -0.081 & 0.39 & 0.49 & 0.90 & -0.035 & 0.049 & 0.70 & -0.10 & 0.56 & 0.64 & 0.65 & 0.70 & -0.12 & 0.04 \\
\hline Dy & -0.12 & 0.031 & 0.085 & 0.041 & -0.17 & $\mathbf{0 . 8 0}$ & 0.54 & -0.016 & -0.14 & 0.43 & -0.063 & 0.050 & 0.80 & 0.17 & -0.077 & 0.082 & -0.24 & 0.79 & 0.11 \\
\hline $\mathrm{Eu}$ & 0.059 & 0.25 & 0.016 & 0.12 & -0.18 & 0.99 & 0.57 & 0.23 & -0.015 & 0.59 & -0.082 & 0.13 & 0.99 & 0.30 & -0.036 & 0.18 & -0.14 & 0.99 & 0.20 \\
\hline Hf & 0.25 & 0.045 & 0.30 & -0.23 & 0.49 & 0.28 & 0.84 & 0.24 & 0.87 & -0.15 & 0.075 & 0.97 & 0.22 & 0.93 & 0.83 & 0.91 & 0.76 & 0.14 & 0.30 \\
\hline $\mathrm{Fe}$ & 0.37 & 0.14 & 0.29 & -0.10 & 0.57 & 0.047 & 0.65 & 0.22 & 0.90 & -0.25 & 0.13 & 0.93 & 0.0065 & 0.82 & 0.83 & 0.83 & 0.83 & -0.073 & 0.33 \\
\hline $\mathrm{La}$ & 0.052 & 0.19 & 0.10 & 0.041 & -0.042 & 0.96 & 0.68 & 0.25 & 0.087 & 0.45 & -0.003 & 0.27 & 0.96 & 0.42 & 0.084 & 0.29 & 0.02 & 0.94 & 0.24 \\
\hline $\mathrm{Lu}$ & 0.024 & 0.23 & 0.00040 & 0.12 & -0.19 & 0.96 & 0.51 & 0.19 & -0.073 & 0.60 & -0.074 & 0.067 & 0.98 & 0.22 & -0.11 & 0.11 & -0.20 & 1.00 & 0.18 \\
\hline $\mathrm{Mg}$ & 1 & 0.65 & -0.42 & 0.54 & -0.12 & 0.032 & 0.16 & 0.43 & 0.52 & 0.41 & -0.14 & 0.19 & 0.063 & 0.12 & 0.52 & 0.28 & 0.50 & 0.029 & -0.24 \\
\hline $\mathrm{Mn}$ & & 1 & -0.44 & 0.32 & 0.063 & 0.21 & 0.066 & -0.090 & 0.17 & 0.65 & -0.069 & 0.0083 & 0.22 & 0.023 & 0.10 & 0.024 & 0.05 & 0.23 & 0.021 \\
\hline $\mathrm{Hg}$ & & & 1 & -0.30 & 0.38 & 0.12 & 0.34 & -0.070 & 0.077 & -0.51 & 0.32 & 0.33 & 0.056 & 0.30 & 0.13 & 0.28 & 0.02 & 0.011 & 0.42 \\
\hline K & & & & 1 & -0.37 & 0.066 & -0.19 & 0.38 & 0.023 & 0.35 & -0.15 & -0.26 & 0.11 & -0.31 & 0.035 & -0.082 & -0.02 & 0.13 & 0.011 \\
\hline $\mathrm{Rb}$ & & & & & 1 & -0.095 & 0.23 & -0.41 & 0.34 & -0.44 & 0.34 & 0.55 & -0.14 & 0.56 & 0.39 & 0.38 & 0.37 & -0.20 & 0.54 \\
\hline $\mathrm{Sm}$ & & & & & & 1 & 0.65 & 0.20 & 0.034 & 0.51 & -0.043 & 0.21 & 0.99 & 0.38 & 0.029 & 0.25 & -0.10 & 0.97 & 0.26 \\
\hline $\mathrm{Sc}$ & & & & & & & 1 & 0.23 & 0.57 & 0.10 & 0.030 & 0.78 & 0.60 & 0.80 & 0.64 & 0.76 & 0.50 & 0.53 & 0.23 \\
\hline $\mathrm{Se}$ & & & & & & & & 1 & 0.43 & 0.18 & -0.062 & 0.19 & 0.22 & 0.19 & 0.33 & 0.35 & 0.39 & 0.21 & -0.13 \\
\hline $\mathrm{Na}$ & & & & & & & & & 1 & -0.090 & 0.041 & 0.86 & -0.0024 & 0.75 & 0.82 & 0.80 & 0.81 & -0.065 & 0.15 \\
\hline $\mathrm{Sr}$ & & & & & & & & & & 1 & -0.23 & -0.24 & 0.54 & -0.15 & -0.20 & -0.21 & -0.25 & 0.60 & -0.24 \\
\hline S & & & & & & & & & & & 1 & 0.13 & -0.059 & 0.035 & -0.013 & 0.028 & 0.00 & -0.092 & 0.15 \\
\hline $\mathrm{Ta}$ & & & & & & & & & & & & 1 & 0.15 & 0.93 & 0.80 & 0.86 & 0.75 & 0.075 & 0.33 \\
\hline $\mathrm{Tb}$ & & & & & & & & & & & & & 1 & 0.32 & 0.0020 & 0.21 & -0.10 & 0.98 & 0.23 \\
\hline Th & & & & & & & & & & & & & & 1 & 0.71 & 0.84 & 0.64 & 0.24 & 0.40 \\
\hline $\mathrm{Ti}$ & & & & & & & & & & & & & & & 1 & 0.80 & 0.92 & -0.10 & 0.15 \\
\hline $\mathrm{U}$ & & & & & & & & & & & & & & & & 1 & 0.72 & 0.14 & 0.37 \\
\hline V & & & & & & & & & & & & & & & & & 1 & -0.19 & 0.11 \\
\hline $\mathrm{Yb}$ & & & & & & & & & & & & & & & & & & 1 & 0.20 \\
\hline $\mathrm{Zn}$ & & & & & & & & & & & & & & & & & & & 1 \\
\hline
\end{tabular}

In bold, significant values (except diagonal) at $\alpha=0.05$

Furthermore, in order to confirm to what extent the elements in the soils contribute to the element contents in lichens, the Enrichment Factor (EF) was calculated for each element $(\mathrm{X})$ according to:

$$
\mathrm{F}(\mathrm{x})=\frac{([x] /[\mathrm{Sm}])_{\text {liq }}}{([x] /[\mathrm{Sm}])_{\text {soil }}}
$$

The concentration of element [X] with subscript "liq" designates the concentration of the element $\mathrm{X}$ in the lichen sample and "soil" for the soil sample of the same site. An EF(x) value greater than 1 indicates that the element in the lichen is enriched compared to the soil.

The elemental concentrations in the lichens from this work were compared with other previously data published from other volcanic areas of the world, which included geothermal fields.

\section{Results}

Lichens of genus Usnea were registered and collected in sites
$\mathrm{CO}, \mathrm{M}, \mathrm{T}, \mathrm{PA}$ and $\mathrm{H}$, all of them growing over rocks. Lichens of genus Protousnea were registered and collected in sites AR, E, H, CA, CC, and R26 over Araucaria araucana. Specimens of both genera were found in site $\mathrm{H}$. Meanwhile, in site RAS no lichen thalli were found.

The elemental concentrations for all lichen samples are shown on Table 1, Supplementary Material.

Most elemental contents in lichen samples and geographical parameters were normally distributed, except variables longitude, Sb, Ca and Cs ( $\mathrm{p} \leq 0.05)$ (Table 3, Supplementary Material). Due to these results, the non-parametric test was done using the Spearman rank correlation, the matrix obtained is shown on Table 2 where the significant variables are highlighted in bold ( $\mathrm{p} \leq 0.05)$.

The elements: Ba, Ca, Ce, Dy, Eu, La, Lu Sc, Tb, Th, Yb and Zn that correlated significantly with the GT (Sm) were tested with the Pearson test and the linear parameters of the elements with significant regressions are shown on Table 3. 
The explained variation by Principal Component Analysis were for Component 1 (PC1) 37\%, Component 2 (PC2) $21 \%$ and Component 3 (PC3) $9 \%$. The additional Principal Components

Table 3: Linear paremetres of the significant regression of the elements with Sm. $(\mathrm{p} \leq 0.05)$.

\begin{tabular}{|c|c|c|c|}
\hline \multicolumn{3}{|c|}{$\mathrm{Y}=\mathrm{a}+\mathrm{bX}$} \\
\hline & $\mathrm{a}$ & $\mathrm{b}$ & $\mathrm{R}^{2}$ \\
\hline Altitude & 129 & 1541 & 0.21 \\
\hline $\mathrm{Ca}$ & 0.50 & 0.24 & 0.18 \\
\hline $\mathrm{Ce}$ & 7.32 & 0.46 & 0.96 \\
\hline $\mathrm{Dy}$ & 0.68 & 0.25 & 0.67 \\
\hline $\mathrm{Eu}$ & 0.17 & 0.025 & 0.93 \\
\hline $\mathrm{La}$ & 3.4 & 0.24 & 0.96 \\
\hline $\mathrm{Lu}$ & 0.052 & 0.00090 & 0.93 \\
\hline $\mathrm{Sc}$ & 0.36 & 0.67 & 0.23 \\
\hline $\mathrm{Tb}$ & 0.14 & 0.000010 & 0.98 \\
\hline $\mathrm{Th}$ & 0.18 & 0.12 & 0.24 \\
\hline $\mathrm{Yb}$ & 0.39 & 0.018 & 0.92 \\
\hline $\mathrm{Zn}$ & 4.1 & 16 & 0.17 \\
\hline & & & \\
\hline
\end{tabular}

contributed less than 9\% (Table 4, Supplementary Material). Figure 2 shows the Principal Component diagrams of the elemental concentration in the lichen samples and geographical parameters ( $\mathrm{PC} 1$ vs $\mathrm{PC} 2$ ), where $\mathrm{GT}$ is represented by $\mathrm{Sm}$ and the lanthanide elements.

Distance to the volcano crater and some geographical parameters are positively correlated with $\mathrm{Ca}, \mathrm{Co}, \mathrm{Mg}, \mathrm{Mn}, \mathrm{K}$, and Se, which distinguish the most distant lichens from the volcano crater ( $\mathrm{H}$ and $\mathrm{AR}$ ); while $\mathrm{Cs}, \mathrm{Hg}, \mathrm{Rb}, \mathrm{S}$ and $\mathrm{Zn}$ negatively correlated, and dispersing lichens close to the crater volcano ( $\mathrm{T}, \mathrm{A}, \mathrm{PA}$ and $\mathrm{E})$ and the thermal areas ( $\mathrm{CO}$ and $\mathrm{M})$.

Arsenic, $\mathrm{Br}, \mathrm{Cr}, \mathrm{Fe}, \mathrm{Na}, \mathrm{V}, \mathrm{Ti}$, and $\mathrm{U}$ correlations are in the positive PC1 and PC2 quadrant, grouping the lichens more close to the lake Caviahue, CA and R26 from CC (Figure 1 and Figure $2 a$ and $2 b$ ).

Lichens of Protousnea genus were separated from those of Usnea (Figure 2c) in agreement with the element composition (Figure 2a). Protousnea lichens are in the positive PC2 and Usnea lichens in the negative PC2 quadrants.

Table 4: Enrichment factors (EF) of the elements in lichens for each sampling site.

\begin{tabular}{|c|c|c|c|c|c|c|c|c|c|c|c|}
\hline Site & $\mathbf{S b}$ & As & $\mathrm{Br}$ & $\mathrm{Ca}$ & Cs & $\mathrm{Hg}$ & K & $\mathbf{R b}$ & $\mathrm{Se}$ & $\mathbf{S}$ & $\mathbf{Z n}$ \\
\hline $\mathrm{H}$ & 0.80 & 1.4 & 3.1 & 0.78 & 0.10 & - & 1.6 & 0.32 & 15 & 16 & 1.0 \\
\hline $\mathrm{H}$ & 0.88 & 1.4 & 2.7 & 2.4 & 0.15 & - & - & 0.51 & 20 & 28 & 1.7 \\
\hline $\mathrm{H}$ & 0.85 & 0.8 & 1.2 & 0.77 & 0.25 & - & 2.3 & 1.0 & 9.9 & 17 & 1.6 \\
\hline $\mathrm{H}$ & 1.3 & 2.4 & 1.9 & 1.7 & 0.31 & - & 5.3 & 1.7 & 18 & 32 & 2.1 \\
\hline $\mathrm{H}$ & 1.1 & 2.2 & 1.9 & 1.3 & 0.19 & - & 3.7 & 1.1 & 39 & 35 & 2.0 \\
\hline $\mathrm{H}$ & 0.5 & 1.7 & 1.3 & 1.0 & 0.12 & - & - & 0.76 & 43 & 30 & 2.0 \\
\hline $\mathrm{H}$ & 1.8 & 3.3 & 6.6 & 0.32 & 0.79 & - & 4.5 & 3.3 & 32 & 50 & 3.5 \\
\hline $\mathrm{AR}$ & 0.26 & 0.34 & 0.87 & 2.3 & 0.088 & - & 1.8 & 0.38 & 8.7 & 17 & 1.0 \\
\hline AR & 0.18 & 0.16 & 0.60 & 2.9 & 0.052 & - & 1.2 & 0.26 & 3.7 & 11 & 0.54 \\
\hline $\mathrm{E}$ & 11 & 0.36 & 1.3 & 1.2 & 0.077 & 4 & 0.76 & 0.24 & 11 & 9 & 1.0 \\
\hline $\mathrm{E}$ & 1.1 & 1.8 & 13 & 1.1 & 0.40 & 13 & - & 1.2 & 23 & 43 & 2.8 \\
\hline E & 1.4 & 0.91 & 3.3 & 1.2 & 0.20 & 12 & 2.4 & 0.85 & 24 & 40 & 2.4 \\
\hline $\mathrm{CA}$ & 0.86 & 1.0 & 2.9 & 1.3 & 0.35 & - & 1.4 & 0.56 & 19 & 16 & 1.8 \\
\hline $\mathrm{CA}$ & 1.1 & 1.3 & 5.1 & 1.3 & 0.64 & - & 1.7 & 0.86 & 19 & 19 & 1.9 \\
\hline $\mathrm{CA}$ & 0.82 & 1.2 & 8.4 & 1.0 & 0.31 & - & 1.6 & 0.67 & 15 & 16 & 1.5 \\
\hline $\mathrm{CA}$ & 0.80 & 1.2 & 8.1 & 1.1 & 0.28 & - & 1.3 & 0.56 & 20 & 21 & 1.6 \\
\hline $\mathrm{CA}$ & 0.86 & 1.3 & 4.2 & 1.4 & 0.25 & - & 1.0 & 0.55 & 16 & 18 & 1.1 \\
\hline PA & 2.2 & 2.1 & 8.6 & 0.37 & 1.1 & - & 3.0 & 2.7 & 21 & 44 & 2.8 \\
\hline $\mathrm{M}$ & 0.26 & 0.59 & 1.2 & 0.26 & 0.80 & 3.3 & 1.4 & 0.58 & 8.5 & 29 & 0.87 \\
\hline $\mathrm{M}$ & 0.26 & 0.41 & 1.6 & 0.30 & 0.61 & 3.1 & - & 0.48 & 6.1 & 21 & 0.83 \\
\hline $\mathrm{CO}$ & 0.81 & 0.81 & 1.5 & 0.20 & 2.5 & 5.0 & 1.3 & 1.7 & 7.9 & 23 & 1.7 \\
\hline $\mathrm{CO}$ & 1.6 & 1.7 & 5.1 & 0.21 & 3.9 & 8.3 & - & 2.9 & 11 & 36 & 3.1 \\
\hline $\mathrm{T}$ & 1.3 & 1.1 & 3.3 & 1.7 & 0.77 & 10.2 & 3.1 & 2.5 & 9.7 & 21 & 2.5 \\
\hline $\mathrm{T}$ & 1.5 & 2.7 & 9.1 & 0.90 & 1.9 & 23.7 & - & 8.4 & 21 & 72 & 3.5 \\
\hline A & 1.3 & 1.9 & 8.5 & 0.23 & 1.5 & - & 1.8 & 2.2 & 6.4 & 63 & 1.6 \\
\hline $\mathrm{CC}$ & 0.21 & 0.37 & 0.85 & 2.3 & 0.073 & - & 0.91 & 0.46 & 2.6 & 13 & 0.79 \\
\hline $\mathrm{CC}$ & 0.33 & 0.61 & 1.5 & 2.0 & 0.16 & - & - & 0.70 & 4.4 & 21 & 1.2 \\
\hline $\mathrm{CC}$ & 0.36 & 0.38 & 1.4 & 1.3 & 0.082 & - & - & 0.50 & 3.7 & 12 & 0.74 \\
\hline R26 & 7.7 & 0.60 & 8.9 & 0.42 & 0.18 & - & 0.85 & 0.37 & 1.9 & 14 & 1.0 \\
\hline R26 & 4.0 & 0.73 & 9.3 & 0.47 & 0.19 & - & - & 0.40 & 2.4 & 18 & 1.2 \\
\hline R26 & 1.9 & 0.61 & 8.4 & 0.83 & 0.13 & - & - & 0.40 & 2.1 & 17 & 1.1 \\
\hline
\end{tabular}



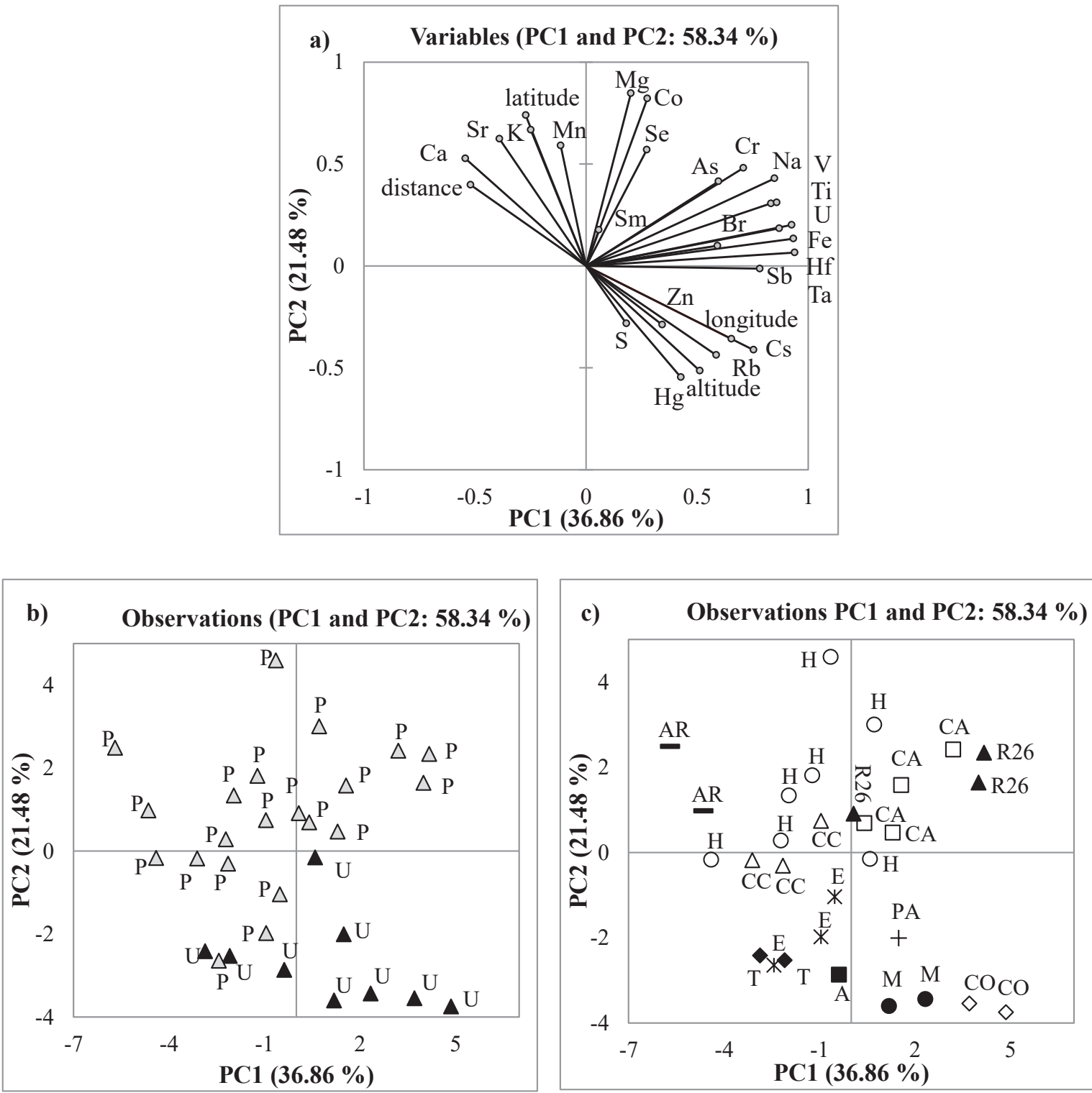

Figure 2: Principal Component Analysis: a) element concentrations and geographical parameters as variables; b) observations of sampling sites: Copahue village (CO), Las Mellizas pond (M), Trolope pond (T), Achacosa pond (A), Puente del Agrio (PA), Escondida waterfall (E), Caviahue village (CA), Caviahue Camping (CC), near to the airfield (R26), Hualcupén lake (H), Las Lecheras stream (AR); $c$ ) observations of Protousnea (P) and Usnea lichens (U).

The EF values of the elements that were $>1$ at least in a single site are shown on Table 4. Bromine, Se, and S were the most enriched (EF up to 70), and $\mathrm{Sb}, \mathrm{As}, \mathrm{Ca}, \mathrm{K}, \mathrm{Rb}$, and $\mathrm{Zn}$ were the less enriched $(\mathrm{EF}:<10)$.

We compared in a descriptive way the elemental concentrations measured in this work with the available data for both fruticose and foliose lichens from volcanic and geothermal active areas of the world. The data are shown on Table 5 .

The lichens from Patagonian volcanoes, Copahue and Puyehue, and other volcanic areas present similar concentrations of $\mathrm{Sb}, \mathrm{As}, \mathrm{Ba}, \mathrm{Br}, \mathrm{Ca}, \mathrm{Ce}, \mathrm{Co}, \mathrm{Cr}, \mathrm{Dy}, \mathrm{Eu}, \mathrm{Hf}, \mathrm{Fe}$, La, Mg, Mn, Sm, Sc and Sr. Meanwhile, V, Ti and Na are higher in the lichens from Mt. Etna and Vulcani volcanoes, followed by those from Patagonia, which clearly show twice to threefold concentration of S. The Hg concentration is highest in Hawaii
( 1 to 2 orders of magnitude), followed by Copahue, Puyehue, Yellostone and Italian volcano areas in decreasing order. The $\mathrm{Zn}$ concentrations are in the same range in all areas.

\section{Discussion}

The S and Se inputs were important for all CopahueCaviahue area, with EF > 5 in all sites. Meanwile, $\mathrm{Br}$ and $\mathrm{Hg}$ EF showed enrichment only in 8 sites respect to the total sampling area. The high variability of all EF analysis did not allow to discriminate major impacted areas. However, the PCA (Figure 2) observations were assembling according to the genera and areas. In the Figure 2c, the separation between Protousnea and Usnea genera, cannot be ensured due to the fact that both genera were found only in the $\mathrm{H}$ area and Usnea thalli observation was poorly explained by PCA. Therefore, the results are discussed based on the Figures $2 a$ and $2 b$. 
Table 5: Ranges, average \pm standard deviation of the element concentration $(\mu \mathrm{g} / \mathrm{gDW})$ in lichens from volcanic and geothermal areas.

\begin{tabular}{|c|c|c|c|c|c|c|c|c|}
\hline Place & Thalli & Genus or species & Reference & Sb & As & $\mathbf{B a}$ & $\mathrm{Br}$ & Cd \\
\hline \multirow[t]{2}{*}{ Copahue Volcano } & Futicose & Usnea $S p$ & 1 & $0.035 \pm 0.010$ & $0.87 \pm 0.23$ & $9 \pm 3$ & $3.9 \pm 1.7$ & $0.130 \pm 0.058$ \\
\hline & Futicose & Protousnea $S p$ & 1 & $0.084 \pm 0.180$ & $0.92 \pm 0.28$ & $11 \pm 4$ & $4.0 \pm 3$ & $<0.10$ \\
\hline Puyehue Volcano & Fruticose & Usnea $S p$ & 4 & $0.034 \pm 0.013$ & $0.92 \pm 0.46$ & $17 \pm 0.14$ & $2.48 \pm 1.3$ & \\
\hline Mt. Etna & Foliose & several species & 24 & $2 \pm 3$ & $2 \pm 1$ & $82 \pm 49$ & $24 \pm 24$ & \\
\hline Vulcano & Foliose & several species & 24 & $6 \pm 21$ & $5 \pm 2$ & $274 \pm 126$ & $31 \pm 17$ & \\
\hline Mt Etna and Vulcano & Fruticose & Ramalina farinacea & 25 & & & & & \\
\hline Whole of the island Hawai & Fruticose & Stereocaulon vulcani & 26 & & & & & \\
\hline Yellowstone, geothermal field & Fruticose & Bryaria. fremontii & 10 & & 0.41-1.18 (ma: 0.62) & & & $0.11-0.41$ (ma. 0.22 ) \\
\hline Yellowstone, geothermal field & Fruticose & Letharia vulpina & 10 & & $0.36-1.16(\mathrm{ma} .0 .62)$ & & & $0.24-0.62(\mathrm{ma} .0 .31)$ \\
\hline Cinnabar and geotermal field & Foliose & Parmelia sp & 11 & & & & & $0.13-0.52$ \\
\hline \multicolumn{9}{|l|}{ Mt. Amiata } \\
\hline Geothermal field, central Italy & Foliose & Parmelia Caperata & 12 & $0.433 \pm 0.188$ & $1.19 \pm 0.79$ & & & $0.329 \pm 0.156$ \\
\hline
\end{tabular}

1- This work

ma.: median

Table 5 (continued)

\begin{tabular}{c|c|c|c|c|c|c|c|c|c|}
\hline Ca & Ce & Cs & Co & Cr & Dy & Eu & Hf & Fe \\
\hline $2383 \pm 2144$ & $7.0 \pm 6.5$ & $0.52 \pm 0.35$ & $0.364 \pm 0.028$ & $0.86 \pm 0.22$ & $0.71 \pm 0.53$ & $0.15 \pm 0.13$ & $0.162 \pm 0.084$ & $1200 \pm 320$ & $3.2 \pm 2.9$ \\
\hline $6800 \pm 6400$ & $6.9 \pm 6.4$ & $0.22 \pm 0.27$ & $0.47 \pm 0.14$ & $1.06 \pm 0.43$ & $0.86 \pm 0.45$ & $0.18 \pm 0.096$ & $0.147 \pm 0.078$ & $1110 \pm 450$ & $3.2 \pm 1.8$ \\
\hline $9402 \pm 3540$ & $5.4 \pm 4.1$ & $0.11 \pm 0.049$ & $0.35 \pm 0.14$ & - & - & $0.21 \pm 0.18$ & $0.12 \pm 0.18$ & $800 \pm 470$ & $2.3 \pm 1.8$ \\
\hline $18716 \pm 22679$ & $21 \pm 12$ & $0.60 \pm 0.30$ & $4 \pm 2$ & $12 \pm 7$ & & $0.40 \pm 0.20$ & $2 \pm 2$ & $9122 \pm 5530$ \\
\hline $21052 \pm 10750$ & $45 \pm 23$ & $3 \pm 1$ & $9 \pm 5$ & $24 \pm 13$ & & $0.50 \pm 0.30$ & $71 \pm 293$ & $11 \pm 6$ \\
\hline
\end{tabular}

\begin{tabular}{|l|l|l|}
\hline $1151-2597$ (ma: 1492$)$ & $0.09-0.23$ (ma: 0.13$)$ & $0.35-1.43$ (ma: 0.50$)$ \\
\hline $2428-5899$ (ma:3718) & $0.14-0.30$ (ma: 0.21$)$ & $0.28-0.92(\mathrm{ma}: 0.54)$ \\
\hline
\end{tabular}

127-251 (ma: 169)

93-444 (ma: 226)

387-1381

$1.15 \pm 0.33$

$4.51 \pm 1.988$

$1019 \pm 449.9$

Table 5 (continued)

\begin{tabular}{|c|c|c|c|c|c|c|c|c|c|}
\hline Lu & Mg & Mn & $\mathrm{Hg}$ & $\mathbf{K}$ & $\mathbf{R b}$ & Sm & Sc & Se & $\mathrm{Na}$ \\
\hline $0.042 \pm 0.040$ & $722 \pm 82$ & $24 \pm 4$ & $0.322 \pm 0.086$ & $2320 \pm 360$ & $10 \pm 2$ & $0.86 \pm 0.83$ & $0.94 \pm 0.41$ & $0.56 \pm 0.25$ & $345 \pm 95$ \\
\hline $0.047 \pm 0.029$ & $841 \pm 166$ & $27 \pm 8$ & $0.264 \pm 0.079$ & $2822 \pm 705$ & $6 \pm 3$ & $0.88 \pm 0.53$ & $0.99 \pm 0.40$ & $0.91 \pm 0.41$ & $398 \pm 193$ \\
\hline \multirow[t]{7}{*}{$0.039 \pm 0.030$} & - & - & $0.175 \pm 0.042$ & $3400 \pm 620$ & $4 \pm 2$ & $0.72 \pm 0.61$ & $0.47 \pm 0.36$ & $0.1904 \pm 0.073$ & $485 \pm 189$ \\
\hline & $3095 \pm 1483$ & $145 \pm 87$ & & $5501 \pm 1602$ & $19 \pm 8$ & $2 \pm 1$ & $3 \pm 2$ & & $2449 \pm 1777$ \\
\hline & $4945 \pm 2907$ & $340 \pm 195$ & & $11460 \pm 5151$ & $49 \pm 23$ & $4 \pm 2$ & $5 \pm 3$ & & $6871 \pm 4645$ \\
\hline & & & $0.152-0.198$ & & & & & & \\
\hline & & & $8-59$ & & & & & & \\
\hline & 324-618 (ma: 429) & 24-105 (ma: 46) & $0.07-0.29$ (ma: 0.14) & 2632-4144 (ma: 3068) & & & & & $22-59$ (ma:36) \\
\hline & 505-908 (ma: 658) & $35-136$ (ma:95) & $0.01-0.24(\mathrm{ma}: 0.10)$ & $1895-3950$ (ma:2793) & & & & & 23-43 (ma: 32) \\
\hline
\end{tabular}

$0.13-0.75$

$85.8 \pm 70.61 \quad 0.199 \pm 0.106$

Table 5 (continued)

\begin{tabular}{|c|c|c|c|c|c|c|c|c|c|}
\hline $\mathbf{S r}$ & $\mathbf{S}$ & $\mathbf{T a}$ & $\mathbf{T b}$ & $\mathbf{T h}$ & $\mathbf{T i}$ & $\mathbf{U}$ & $\mathbf{V}$ & $\mathbf{Y b}$ & $\mathbf{Z n}$ \\
\hline $14 \pm 4$ & $3780 \pm 210$ & $0.0161 \pm 0.0078$ & $0.12 \pm 0.12$ & $0.40 \pm 0.27$ & $211 \pm 64$ & $0.074 \pm 0.040$ & $3.22 \pm 0.80$ & $0.31 \pm 0.29$ & $24 \pm 7$ \\
\hline $25 \pm 18$ & $3500 \pm 430$ & $0.0140 \pm 0.0080$ & $0.28 \pm 0.19$ & $0.28 \pm 0.19$ & $215 \pm 104$ & $0.068 \pm 0.033$ & $3.2 \pm 1.4$ & $0.36 \pm 0.22$ & $20 \pm 5$ \\
\hline $27 \pm 6$ & $11700 \pm 1400$ & $0.0117 \pm 0.0088$ & $0.098 \pm 0.081$ & $0.20 \pm 0.16$ & - & $0.078 \pm 0.057$ & - & - & $0.29 \pm 0.22$ \\
\hline $110 \pm 69$ & & $0.40 \pm 0.50$ & & $2 \pm 1$ & $1036 \pm 664$ & & $36 \pm 7$ \\
\hline $224 \pm 152$ & & $0.50 \pm 0.80$ & & $8 \pm 5$ & $1195 \pm 619$ & & $55 \pm 29$ & \\
\hline
\end{tabular}

719-1372 (ma: 979)

635-1163 (ma: 802)

1528-2861

\begin{tabular}{|c|c|}
\hline $7-22$ (ma:9) & $0.13-0.58$ (ma:26) \\
\hline $8.27-26$ (ma: 16$)$ & $0.14-0.81$ (ma: 0.43 )
\end{tabular}

$0.13-0.58$ (ma:26)
$0.14-0.81$ (ma: 0.43$)$

16-35 (ma:23)

21-38 (ma: 26)

27-114 
Thermal and other areas close to the crater volcano $(S$, $\mathrm{Hg}, \mathrm{Rb}, \mathrm{Cs}$ and $\mathrm{Zn}$ )

The region called "Caldera del Caviahue" comprises the crater zone and thermal areas with emissions of hot fluids where $\mathrm{CO}$ and $\mathrm{M}$ areas are located. Thermal discharges of water vapor, acid gases and hydrocarbons have been detected in this region by Agusto and Vélez [17]. All our sampling sites, except for $\mathrm{H}$ and $\mathrm{AR}$, were located in the Caldera del Caviahue.

Sulphur dioxide is one of the gases frequently emitted by volcanic activity, following water vapor and $\mathrm{CO}_{2}$. Copahue is the second most active terrestrial volcano, which has ejected the largest amount of pyroclastic sulphur $(\sim 80 \%)$, followed by the Poás Volcano in Costa Rica [27,28]. Tamburello, et al. [29] measured gaseous emissions of $\mathrm{SO}_{2}, \mathrm{CO}_{2}, \mathrm{HCl}, \mathrm{HBr}$ and $\mathrm{H}_{2}$ from the Copahue crater zone in March 2013 and 2014, detecting very high $\mathrm{SO}_{2}$ densities of up to $2000 \mathrm{ppm}$ in the Copahue crater lake.

The lichens sampled in the areas close to the crater, within thermal area as $\mathrm{CO}, \mathrm{M}$, and others such as PA, T, A and E were grouped according to larger $\mathrm{S}, \mathrm{Hg}, \mathrm{Rb}, \mathrm{Cs}$ and $\mathrm{Zn}$ concentrations. However, Cs and $\mathrm{Hg}$ were the only that correlated significantly with the distance to the crater ( $\mathrm{p} \leq 0.05$, Table 2$)$. The prevailing westerly winds could carry elements from the geothermal vents towards the $\mathrm{CO}, \mathrm{M}, \mathrm{A}$ and $\mathrm{T}$ areas. This may explain the negative correlation with the crater distance and the EF values (Table 4). Those results are also in agreement with Copahue volcano crater random emissions, showed by the variation of $\mathrm{SO}_{2}$ fluxes measured by Agusto and Vélez [17].

Most elemental concentrations observed in fruticose lichens from Copahue as well as lichens from the same volcanic arch, as Puyehue Cordón Caulle Complex, are in the range of other volcanic areas in the world. Nevertheless, the S concentration from Patagonian volcanoes is clearly two to three times larger than concentrations found in other areas (Table 5). This is consistent with Tamburello et al. [29] who reported that Copahue volcano crater lake has the highest $\mathrm{SO}_{2}$ concentrations in the world.

\section{Areas close to Caviahue lake (As, $\mathrm{Sb}, \mathrm{Br}, \mathrm{Cr}$ and litho- phile elements)}

The correlation among $\mathrm{As}, \mathrm{Cr}, \mathrm{Br}, \mathrm{Fe}$ and $\mathrm{Sb}$ elements grouped the lichens from CA and R26. Those elements, except As, could be associated with the PM in spite of absent relation with GT. Scandium is a transition metal with similar characteristics to lanthanide elements and the GT, which correlated with the volcano crater distance $(\mathrm{p} \leq 0.05$, Table 2$)$ and with $\mathrm{Cr}, \mathrm{Br}, \mathrm{Fe}$ and $\mathrm{Sb}$. These correlations allow to link these elements with the volcanic ash plumes.

Copahue's 2000 eruption was probably one of the substantial contributors to elemental composition in lichens from the CA, CC and R26 areas. The ashes deposited during the event were several centimeters more than the others areas. In addition, Delpino and Bermúdez [30] reported that the ashes were enriched in S, As, Ta, and Ti.
The main ash deposition site induced by atmospheric conditions (wind, rain and snow) and topography was located close to the Caviahue lake (Figure 1). It included the Caviahue village, the Escondida waterfall, especially in the western sector. The pyroclastic emissions were accompanied by clouds of gases that swept the RAS valley, grazing the ground as far as the Caviahue depression, $10 \mathrm{~km}$ away from the volcano crater. This phenomenon generated acid rain and volcanic smog accompanied by the smell of S gases [30]. The acid atmospheric condition probably favored the ash leaching, increasing the availability of elements for the lichens. In addition, the evaporation of the crater lake, which disappeared completely in the 2000 eruption, could have contributed to the accumulation of chalcophile elements contents such as As, Sb and Se in the lichens. Another contribution to the availability of elements of volcanic origin can be found in the large amounts of sediments, including glacial debris and hydrothermally altered clays, carried by the two tributary rivers, the RAS and the Dulce river, into the Caviahue lake, especially during volcanic eruptions Varekamp [31] and Pedrozo et al. [32] found major concentrations of $\mathrm{S}, \mathrm{K}, \mathrm{Ca}, \mathrm{Fe}, \mathrm{Mn}, \mathrm{Zn}, \mathrm{As}$, and $\mathrm{Pb}$ in RAS water, while $\mathrm{Cr}, \mathrm{Ni}$ and $\mathrm{Cu}$ were detected only in the Caviahue lake. The high concentrations of elements found in the RAS water reflect a great degree of contamination which may explain the absence of lichens close to this river. The strong Patagonian winds enable thermal and chemical homogenization of Caviahue water lake [31] and spread water vapor enriched in elements such as $\mathrm{As}, \mathrm{Br}, \mathrm{Se}, \mathrm{Sb}$ and $\mathrm{Hg}$. This may explain the higher concentrations in the lichens in the surroundings of this lake.

Some elements (i.e. As, $\mathrm{Br}, \mathrm{Cr}$ and $\mathrm{Sb}$ ), in particular in CA and R26 could have anthropic contribution. However, the Caviahue settlement is small, with only 608 permanent inhabitants (INDEC, http://www.indec.gob.ar). A mechanical workshop and an airfield are located close to CA and R26. The higher EF values (3-9), particularly in R26 (9), and the correlation among $\mathrm{As}, \mathrm{Br}, \mathrm{Cr}$ and $\mathrm{Sb}$, could be a result of the anthropic influence. Similar findings have been reported by Varrica, et al. [5] in lichens from the Etna Volcano vicinity.

Protousnea lichens from CA, CC, R26 and some from $\mathrm{H}$ present particular morphological characteristics, such as numerous fibrils arranged as short straight hairs, especially in CA. Habitat factors often modify the structure of thalli manifesting eco-morphological differentiation [33]. Some authors mention the importance of considering lichen thallus surface features such as cilia, pits, isidia, surface roughness and holes, which can determine the efficiency of particle entrapment $[6,34]$. In our case, the peculiar thallus growth may be a consequence of environmental alteration due to volcanic activity, and may also have had an influence on the uptake of some elements, especially in CA.

Areas outside to the Caldera del Caviahue ( $\mathrm{Ca}, \mathrm{Sr}, \mathrm{K}, \mathrm{Mn}$, $\mathrm{Mg}, \mathrm{Co}$ and $\mathrm{Se}$ )

The higher concentration of the biological elements (Ca, $\mathrm{K}, \mathrm{Sr}, \mathrm{Mg}, \mathrm{Mn}$, Co and Se) in lichens of the most distant areas from the volcano crater, $\mathrm{H}$ and $\mathrm{AR}$ sites, together with 
the lower concentration of toxic elements ( $\mathrm{Hg}$ and $\mathrm{S}$ ) could indicate that these lichens have been less damaged than those close to the volcano crater ( $\mathrm{M}, \mathrm{CO}$ and $\mathrm{PA})$; Figure $2 \mathrm{a}$ and $2 \mathrm{~b}$. Although, $\mathrm{K}$ and $\mathrm{Mg}$ could come together with the PM, they are soluble; they do not maintain their proportions with those lanthanides and being essential elements are bioaccumulated by the lichens. Potassium concentrations in lichens have been observed to decrease subsequent to cell membrane damage following pollution by $\mathrm{SO}_{2}$ and heavy metals [6]. The effect of $\mathrm{SO}_{2}$ fumigation induced changes in chlorophyll fluorescence, indicating photosynthesis inhibition [35].

The absence correlation of Se with the GT in the lichens and the high EF Se values in the lichens evidence a great contribution of this element in the gas form. Predominant plume direction in the 2012 and 2016 eruptions [28,36] may have had a great influence on Se accumulation in the lichens over these areas. This is consistent with Se content in pyroclastic material from the 2012 event and the high concentrations measured in leachates in ashes from 2016 eruption $[36,37]$.

\section{Conclusions}

Lichen elemental composition reflects the impact of the volcanic eruptions and the permanent geothermic activity according to what was expected. The concentrations of the elements in the lichens are mainly influenced by the crater volcano distance and the wind. This last factor plays the most important role in the dispersion of the Copahue volcanic products as ash plumes, degasing from hydrothermal vents and evaporation from the water bodies.

The Agrio Upper river is the greatest impacted site where lichens are totally absent. Likewise, the sites on the northern edge of the Caviahue lake could have an anthropic contribution overlap those volcanic products.

The concentrations of nontoxic elements and the higher of the biological elements ( $\mathrm{Ca}, \mathrm{K}, \mathrm{Se}, \mathrm{Mg}, \mathrm{Mn}$ ) in lichens from Hualcupén lake and Las Lecheras stream, the most distant areas from the volcano crater, allow to classify them as the less impacted areas.

Sulphur concentrations found in lichens from the CopahueCaviahue Volcanic Complex, as well as those previously reported for Puyehue-Cordón-Caulle Complex, are two to three times higher than other volcanic areas of the world.

The results of this study strengthen the practice on the use of lichens for bioindicator/biomonitor studies in geothermal areas as natural laboratories.

The permanent Copahue-Caviahue Volcanic Complex activity provides a favorable scenario to continue investigating the response of lichens to these impacts.

\section{Acknowledgment}

The authors acknowledge to Ricardo Sánchez for his participation in sampling, also to Dr. Romina Daga for providing us the existing information on the geological studies carried out in the Volcán Copahue area. We want also to thank to the RA- 6 reactor staff for the irradiation of the samples and to the Chemical Laboratory, INVAP SE, staff for the support and assistance in the sample analysis. This work was funded by PICT 2015-1269 project. MIM is grateful to Consejo Nacional de Investigaciones Científicas y Técnicas and Universidad Nacional del Comahue.

\section{References}

1. Mather TA, Pyle DM, Oppenheimer C (2003) Tropospheric Volcanic Aerosol. Volcanism and the Earth's Atmosphere, Geophysical Monograph 139 American Geophysical Union 189-212. Link: https://bit.ly/349GjMQ

2. Nriagu J, Becker C (2003) Volcanic emissions of mercury to the atmosphere: global andregional inventories. The Science of the Total Environment 304 3-12. Link: https://bit.ly/3e3iWcy

3. Bargagli R (2005) Persistent Contaminants in the Antarctic Atmosphere In: Caldwell MM, Heldmaier G, Jackso RB, Lange OL, Mooney HA, Schulze ED, Sommer U eds. Antarctic ecosystems. Environmental contamination, climate change, and human impact. Berlin: Springer 175: 125-162. Link: https://bit.ly/3dW7EGI

4. Bubach DF, Dufou L, Perez Catán S (2014) Evaluation of dispersal volcanic products of recent events in lichens in environmental gradient, Nahuel Huapi National Park, Argentina. Environ Monit Assess 186: 4997-5007. Link: https://bit.ly/2UGs8ff

5. Varrica D, Aiuppa A, Dongarrá G (2000) Volcanic and anthropogenic contribution to heavy metal content in lichens from Mt. Etna and Vulcano Island (Sicily). Environmental Pollution 108: 153-162. Link: https://bit.ly/2V0ijrp

6. Garty J (2001) Biomonitoring atmospheric heavy metals with lichens: Theory and Application. Critical Reviews in Plant Sciences 20: 309-371. Link: https://bit.ly/349v0nN

7. Nimis PL, Scheidegger C, Wolseley PA (2002) Monitoring with Lichens Monitoring Lichens. Springer Science Busines Media BV. Link: https://bit.ly/2UF22Jm

8. Garty J, Haya L, Garty-Spitz LR, Ganor E, Stupp A, et al. (2008) Temporal fluctuations of mineral concentrations as related to the physiological status of the lichen Ramalina lacera (With.) J. R. Laund. Isr. Journal of Plant Sciences 56: 361-369. Link: https://bit.ly/3aNFn3u

9. Boamponsen LK, Freitas CR, Williams D (2017) Source apportionment of air pollutants in the Greater Auckland Region of New Zealand using receptor models and elemental levels in the lichen, Parmotrema reticulatum. Atmospheric Pollution Research 8: 101-113. Link: https://bit.ly/2UFMMvL

10. Bennett JP, Wetmore CM (1999) Geothermal elements in lichens of Yellowstone National Park, USA. Environmental and Experimental Botany 42 191-200. Link: https://bit.ly/2xR8jZq

11. Loppi S (2001) Environmental distribution of mercury and other trace elements in the geotermal area of Bagnore (Mt. Amiata, Italy). Chemosphere 45: 991 995. Link: https://bit.ly/3aL21JM

12. Loppi S, Bargagli R (1996) Lichen biomonitoring of trace elements in a geothermal area (Central Italy). Water, Air \& Soil Pollution 88: 177-187. Link: https://bit.ly/2V3hmyn

13. Bubach DF, Perez Catán S, Arribére MA Ribeiro Guevara S (2012) Bioindication of volatile elements emission by the Puyehue-Cordón Caulle (North Patagonia) volcanic event in 2011. Chemosphere 88: 584-590. Link: https://bit.ly/2X4Hb3X

14. Nelson PR, Wheeler TB (2016) Persistence of epiphytic lichens along a tephra-depth gradient produced by the 2011 Puyehue-Cordón Caulle eruption in Parque Nacional Puyehue, Chile. Bosque 37: 97-105. Link: https://bit.ly/2X9Mqj0

Citation: Bubach DF, Catán SP, Messuti MI, Arribére MA, Guevara SR (2020) Bioaccumulation of trace elements in lichens exposed to geothermal and volcanic activity from copahue-caviahue volcanic complex, patagonia, Argentina. Ann Environ Sci Toxicol 4(1): 005-015. D0I: https://dx.doi.org/10.17352/aest.000019 
15. Conti ME, Jasan R, Finoia MG, lavicoli I, Plá R (2016) Trace elements deposition in the Tierra del Fuego region (south Patagonia) by using lichen transplants after the Puyehue-Cordón Caulle (north Patagonia) volcanic eruption in 2011 Environmental Science Pollution Research International. 23: 6574-6483. Link: https://bit.ly/39K7ajl

16. Stern CHR (2004) Active Andean volcanism: its geologic and tectonic setting Revista Geológica de Chile 31: 161-206. Link: https://bit.ly/2Ul8T4I

17. Agusto MR, Vélez M (2017) Avances en el conocimiento del sistema volcánico-hidrotermal del Copahue: a 100 años del trabajo pionero de Don Pablo Groeber. Revista de la Asociación Geológica Argentina 74: 109-124. Link: https://bit.ly/2JFmvaF

18. Shevko EP, Bortnikova SB, Abrosimova NA, Kamenetsky VS, Bortnikova SP, et al (2018) Trace Elements and Minerals in Fumarolic Sulfur: The Case of Ebeko Volcano, Kuriles. Geofluids Volume 2018, Article ID 4586363. Link: https://bit.ly/34grg4c

19. Cabrera AL, Willink A (1980) Biogeografía de América Latina. Segunda edición corregida. Monografía 13. Serie de Biología. Secretaría General de la Organización de los Estados Americanos. Washington DC, United States. Link: https://bit.ly/2x4Fmt0

20. Smodiš B, Bleise A (2002) Internationally harmonized approach to biomonitoring traceelement atmospheric deposition. Environmental Pollution 120: 3-10. Link: https://bit.ly/2X7KmrG

21. Smodiš B (2003) IAEA Approaches to assessment of chemical elements in atmosphere. In: Markert BA, Breure AM, https://bit.ly/3dW1EOa Zechmeister $\mathrm{HG}$ (Eds). Bioindicators and biomonitors, principles, concepts and applications. Elsevier, Amsterdam 875-902. Link:

22. Stevens GN (1999) A revison of the lichen family Usneaceae in Australia Bibliotheca Lichenologica 72: 1-128. Link: https://bit.ly/2JApXU4

23. David MB, Harrison RB (1989) Analysis of sulfur in soil, plant and sediment materials: sample handling and use of an automated analyzer. Soil Biology and Biochemistry 2I: 119-123. Link: https://bit.ly/34fDFFp

24. Grasso MF, Clocchiatti R, Carrot F, Deschamps C, Vurro F (1999) Lichens as bioindicators in volcanic areas: Mt. Etna and Vulcano Island (Italy). Environmental Geology 37: 207-217. Link: https://bit.ly/3bJDEvU

25. Bargagli R, Barghigiani C (1991) Lichen biomonitoring of mercury emissions and deposition in mining, geothermal and volcanic areas of Italy. Environmental Monitoring and Assesment 16: 265-275. Link: https://bit.ly/2JEFeTW

26. Davies F, Notcutt G (1996) Bomonitoring of atmospheric mercury in the vicinity of Kilauea, Hawaii. Water, Air \& Soil Pollution 86: 275-281. Link: https://bit.ly/3dQGKQB

27. Delpino D, Bermúdez A (1993) La actividad del Volcán Copahue durante 1992. Erupción con emisiones de azufre piroclástico. In: XII Congreso Geológico Argentino y II Congreso de Exploración de Hidrocarburos. Mendoza, Argentina.

28. Petrinovic IA, Villarosa G, D’elia L, Guzmán SP, Páez GN, et al. (2014) La erupción del 22 de diciembre de 2012 del volcán Copahue, Neuquén Argentina: caracterización del ciclo eruptivo y sus productos. Revista de la Asociación Geológica Argentina 71: 161-173. Link: https://bit.ly/2X9SHeb

29. Tamburello G, Agusto M, Caselli A, Tassi F, Vaselli O, et al. (2015) Intense magmatic degassing through the lake of Copahue volcano, 2013-2014. Journal of Geophysical Research: Solid Earth 120: 6071-6084. Link: https://bit.ly/2UK3udL

30. Delpino DH, Bermúdez AM (2002) La erupción del Volcán Copahue del año 2000. Impacto social y al medio natural. Actas del XV Congreso Geológico Argentino. El Calafate, Santa Cruz, Argentina.
31. Varekamp JC (2008) The volcanic acidification of glacial Lake Caviahue Province of Neuquen, Argentina. Journal of Volcanology and Geothermal Research 178: 184-196. Link: https://bit.ly/2x3FmcN

32. Pedrozo F, Kelly L, Díaz M, Temporetti P, Baffico G, et al. (2001) First results on the water chemistry, algae and trophic status of an Andean acidic lake system of volcanic origin in Patagonia (Lake Caviahue). Hydrobiologia 452: 129-137. Link: https://bit.ly/34b5rD1

33. Osyczka P, Boroń P, Lenart-Boroń A, Rola K (2018) Modifications in the structure of the lichen Cladonia thallus in the aftermath of habitat contamination and implications for its heavy-metal accumulation capacity. Environmental Science and Pollution Research 25, 1950-1961. Link: https://bit.ly/2V58poi

34. Perez Catán S, Messuti MI, Bubach DF (2019) A new measurement tool to consider for airborne pollutants evaluations using lichens. Environmental Science and Pollution Research. Link: https://bit.ly/2R9LgQp

35. Gries C, Sanz MJ, Nash III TH (1995) The effect of $\mathrm{SO}_{2}$ fumigation on $\mathrm{CO}_{2}$ gas exchange, chlorophyll fluorescence and chlorophyll degradation in different lichen species from western North America. Cryptogame Botany 5: 239-246. Link: https://bit.ly/2R789E3

36. Paez PA, Caselli AT, Cogliati MG, Monasterio AM (2017). Estudio Del Impacto De Emisiones De Cenizas Volcánicas Provenientes Del Volcán Copahue. Link: https://bit.ly/2JEeK56

37. Daga R, Caselli A, Ribeiro Guevara S, Agusto M (2017) Tefras emitidas durante la fase inicial hidromagmática (julio de 2012) del ciclo eruptivo 2012-actual (2016) del Volcán Copahue (Andes del sur). Revista de la Asociación Geológica Argentina 74: 191-206. Link: https://bit.ly/2yt67rr

Discover a bigger Impact and Visibility of your article publication with Peertechz Publications

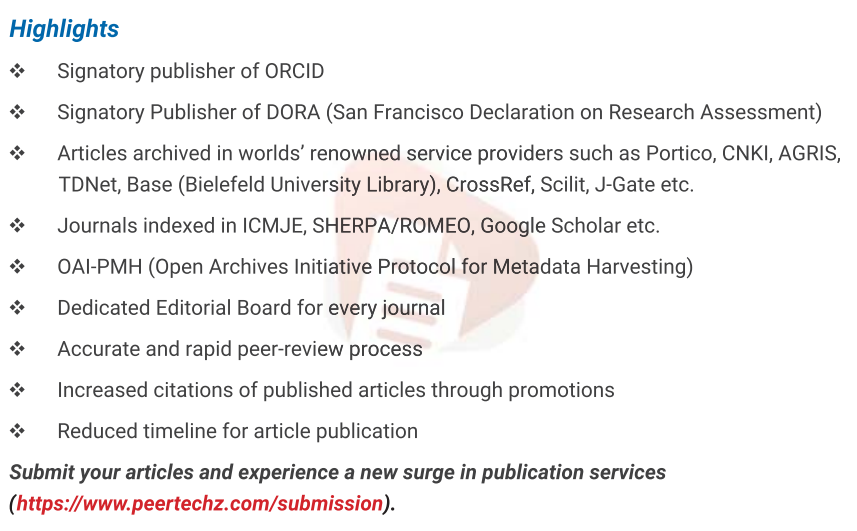

Peertechz journals wishes everlasting success in your every endeavours

Copyright: $\odot 2020$ Bubach DF, et al. This is an open-access article distributed under the terms of the Creative Commons Attribution License, which permits unrestricted use distribution, and reproduction in any medium, provided the original author and source are credited.

Citation: Bubach DF, Catán SP, Messuti MI, Arribére MA, Guevara SR (2020) Bioaccumulation of trace elements in lichens exposed to geothermal and volcanic activity from copahue-caviahue volcanic complex, patagonia, Argentina. Ann Environ Sci Toxicol 4(1): 005-015. DOI: https://dx.doi.org/10.17352/aest.000019 